\title{
Poboliǰanje održavanja sustava navlaživanja u klasičnim komornim sušionicama
}

\section{Improving of Maintenance of Humidifying System in Conventional Wood Kiln Dryers}

\author{
Izvorni znanstveni rad • Original scientific paper \\ Prispjelo-received: 27. 10. 2011. \\ Prihvaćeno-accepted: 16. 5. 2012. \\ UDK: $630 * 847.22 ; 674.047 .3$ \\ doi:10.5552/drind.2012.1131
}

\begin{abstract}
SAŽETAK • Pri sušenju drva vrlo je čest problem taloženje vodenog kamenca na sastavne dijelove sušionica, posebno na sapnicama za raspršivanje vode, što je posljedica upotrebe „,tvrde“ i tehnološki nepripremljene vode. Često se upotrebljavaju neodgovarajuća sredstva za uklanjanje kamenca, koja štetno djeluju na opremu i ljude. Kako bi se smanjili materijalni troškovi nastali uporabom neodgovarajućih sredstava za uklanjanje kamenca $i$ spriječilo potencijalno štetno djelovanje na zdravlje radnika, u ovom je radu istražena mogućnost primjene limunske kiseline u postupcima uklanjanja kamenca sa sapnica navlaživača klasičnih komornih sušionica. Tretirane su rabljene i nerabljene metalne sapnice navlaživača klasičnih komornih sušionica, pri čemu su primijenjene različite koncentracije vodene otopine limunske kiseline sobne temperature te provrela otopina (trajanje vrenja 5 i 10 minuta). Utvrđeno je da vodena otopina limunske kiseline sobne temperature ne daje pozitivne rezultate, dok čišćenje sapnica provrelom vodenom otopinom limunske kiseline već pri najmanjim koncentracijama daje iznimno dobre rezultate glede čišćenja kamenca i korozije, čime se postiže ponovna potpuna funkcionalnost sapnica. Nisu utvrđene negativne posljedice djelovanja limunske kiseline na tijelo metalnih sapnica.
\end{abstract}

Ključne riječi: klasična komorna sušionica, sušenje drva, sapnice navlaživača, vodeni kamenac, limunska kiselina monohidrat

\begin{abstract}
During wood drying, the formation of limescale deposits on conventional drying kiln components frequently causes difficulties, especially on nozzles for dispersion of water mist, as a result of the use of "hard water" and technologically unprepared water. Frequently inadequate cleaners for the removal of limescale are used, which have harmful effects on the equipment and people. In order to reduce costs incurred due to the use of inadequate cleaners for the removal of limescale and to eliminate potentially harmful effects on the health of employees, the use of citric acid has been researched in procedures of removal of limescale from the moisturizer nozzles of the conventional drying kilns. Used and unused metal moisturizer nozzles of the conventional drying kilns have been treated with different concentrations of water solution of citric acid at ambient temperature and in boiled state for 5 and 10 minutes. It has been determined that the water solution of citric acid at ambient temperature does not give positive results, while the treatment of nozzles in the boiled water solution of citric acid gives very good results already at minimum concentration of citric acid, both for the cleaning of limescale and for the cleaning of corrosion, resulting in fully renewed functionality of nozzles. No adverse effects of citric acid on the body of metal nozzles have been recorded.
\end{abstract}

Key words: conventional wood drying kiln, wood drying, moisturizer nozzles, limescale, citric acid monohydrate

\footnotetext{
${ }^{1}$ Autori su asistent i izvanredni profesor na Šumarskom fakultetu Sveučilišta u Zagrebu, Hrvatska.

${ }^{1}$ The authors are assistant and associate professor at the Faculty of Forestry, University of Zagreb, Croatia.
} 


\section{UVOD}

\section{INTRODUCTION}

Kako se ljudi od prapovijesti koriste drvom, postoji i potreba za sušenjem drva iako se postupak koji mi danas poznajemo kao klasično komorno sušenje pojavljuje tek potkraj 19. stoljeća u Europi. Prije toga se drvo sušilo samo prirodnim putem. Potkraj 19. stoljeća francuske i pruske željeznice razvijaju sušionice za drvo u kojima drvo za vrijeme sušenja ne dolazi u dodir s dimnim plinovima, a tek od 1920. godine sušionice nalaze široku primjenu u drvnoj industriji i sve se više usavršavaju (Krpan, 1965). Klasično komorno (evaporacijsko) sušenje najzastupljeniji je i najistraživaniji oblik umjetnog sušenja drva u svijetu, i to zbog svoje ekonomičnosti, cijene, jednostavnosti uporabe i vođenja procesa sušenja te mogućnosti da se drvo prilično brzo osuši do najnižih sadržaja vode u drvu.

Bitan dio opreme u klasičnoj komornoj sušionici jesu navlaživači zraka. Kako se u praksi primjenjuju dva načina navlaživanja zraka unutar klasične komorne sušionice - raspršenom vodenom maglom i zasićenom vodenom parom, uvjeti unutar sušionice u kojima se drvo suši mješavina su zraka i vodene pare temperature do $100{ }^{\circ} \mathrm{C}$ (Pervan, 2000). Zbog navlaživanja vodom u takvim se mikroklimatskim uvjetima vodeni kamenac (uglavnom karbonatne soli kalcija) iz vode taloži na sapnicama navlaživača. Naslage kamenca iz prirodnih voda često uzrokuju brojne tehničke i ekonomske probleme $u$ industrijskim postrojenjima $\mathrm{i}$ kućnoj opremi time što uzrokuju otežan protok vode u cijevima i sapnicama ili ograničavaju prijenos topline u izmjenjivačima topline (Legrand i Leroy, 1990). Naslage kamenca nastaju i na membranama sustava reverzne osmoze, a najčešće se sastoje od kalcijeva karbonata i kalcijeva sulfata (Baker i dr., 1997). Činitelji koji obično utječu na nastanak naslaga kalcijeva karbonata jesu razina prezasićenosti, $\mathrm{pH}$, temperatura i brzina toka vode (MacAdam i Parsons, 2004). Pri zagrijavanju vode najlakše se taloži kalcijev karbonat, koji se izlučuje toplinskim raspadanjem kalcijeva bikarbonata zbog otplinjavanja slobodne pripadne ugljične kiseline, pa su stoga procesi raspadanja kalcijeva bikarbonata i taloženje kalcijeva karbonata upola sporiji u zatvorenim vodnim sustavima i uglavnom su prouzročeni trošenjem ugljične kiseline na korozijske procese. Proces taloženja počinje već pri temperaturi od 20 do $30{ }^{\circ} \mathrm{C}$, a intenzivira se s povišenjem temperature, tako da je na $100{ }^{\circ} \mathrm{C}$ raspadanje gotovo potpuno (Šivak, 2002). Najčešći uzrok taloženja kamenca na sapnicama navlaživača jest to što se u drvnoindustrijskoj praksi za navlaživanje često upotrebljava tvrda i tehnološki nepripremljena voda, što s vremenom trajanja procesa sušenja drva dovodi do potpunoga ili djelomičnog začepljenja sapnica navlaživača. To uzrokuje teškoće u održavanju zadanih parametara sušenja te je moguć nastanak grešaka sušenja. Topljivost soli tvrdoće $u$ vodi smanjuje se zagrijavanjem te se one talože kao tvrdi talog, a kako su u sušionicama temperature zraka do $100{ }^{\circ} \mathrm{C}$, vodeni se kamenac taloži na sapnicama zbog izloženosti višim temperaturama i mogućnosti lakšeg otplinjavanja slobodne pripadne ugljične kiseline. Taloženjem kamenca smanjuje se uporabna funkcija sapnica, te one više ne stvaraju finu raspršenu vodenu maglu nego zbog začepljenja polijevaju građu mlazom vode ili se sapnice potpuno začepe, što osim utjecaja na kvalitetu vođenja procesa sušenja i postizanja željenih parametara vlage unutar sušionice, dovodi i do pada kvalitete osušenog drva.

Prema provedenom istraživanju ukupne tvrdoće (tabl. 2), vode u Republici Hrvatskoj općenito se mogu kategorizirati kao srednje tvrde do tvrde (tabl. 1), pri čemu je problem tvrdoće izraženiji u primorskoj Hrvatskoj, osobito na otocima (Dadić, 2001). Na temelju tih spoznaja bez adekvatne tehnološke pripreme vode u drvnoj će se industriji pojavljivati problem taloženja vodenog kamenca na sapnicama navlaživača.

U praksi se čišćenje sapnica često provodi klorovodičnom kiselinom, tzv. solnom kiselinom $(\mathrm{HCl})$ ili drugim neodgovarajućim sredstvima. Problem čišćenja klorovodičnom kiselinom jest njezina jačina i korozivna svojstva - ona nagriza metalnu površinu sapnica. Nakon nekoliko čišćenja klorovodičnom kiselinom sapnice gube svoje nazivne dimenzije i postaju neupotrebljive. Cijena metalnih sapnica prilično je visoka, stoga čišćenje klorovodičnom kiselinom uzrokuje nepotrebne troškove u sušioničkoj praksi. Osim toga, plastične se sapnice ne mogu čistiti klorovodičnom kiselinom. Klorovodična je kiselina također opasna za rukovanje, što od radnika u sušionicama zahtijeva poznavanje sigurnog načina rada s opasnim tekućinama, jer one djeluju nagrizajuće, uz opasnost oštećivanja dišnih organa, očiju, crijeva i kože. Najmanji stupanj zaštite tijekom rukovanja klorovodičnom kiselinom trebala bi biti uporaba zaštitnih gumenih ili PVC rukavica te nošenje zaštitnih naočala, a bilo bi poželjno nositi i kemijski otpornu odjeću i obuću. Opasnost od klorovodične kiseline ovisi i o njezinoj koncentraciji, a opasna je i u dodiru s određenim materijalima te pri miješanju s vodom, pri čemu može izazvati burne reakcije. Članak 17. Zakona o zaštiti na radu (NN 59/96, 94/96, 114/03, 100/04, 86/08, 116/08 i 75/09) obvezuje poslodavca na primjenu pravila zaštite na radu na temelju općih načela zaštite, i to na zamjenu opasnoga

Tablica 1. Klasifikacija prirodnih voda s obzirom na ukupnu tvrdoću (izvor: Šivak, 2002)

Table 1 Classification of natural waters with respect to total hardness (source: Šivak, 2002)

\begin{tabular}{|l|c|c|c|}
\hline \multirow{2}{*}{\multicolumn{1}{|c}{$\begin{array}{c}\text { Klasa vode } \\
\text { Water class }\end{array}$}} & \multicolumn{3}{|c|}{$\begin{array}{c}\text { Ukupna tvrdoća } \\
\text { Total hardness }\end{array}$} \\
\cline { 2 - 4 } & ${ }^{\circ} \mathrm{nj}$ & $\mathrm{mol} / \mathrm{m}^{3}$ & $\mathrm{mg} \mathrm{CaCo} / \mathrm{L}$ \\
\hline $\begin{array}{l}\text { Vrlo mekane } \\
\text { Very soft }\end{array}$ & $0-4$ & $0-0,72$ & $0-71,40$ \\
\hline Mekane / Soft & $4-8$ & $0,72-1,43$ & $71,40-142,80$ \\
\hline $\begin{array}{l}\text { Srednje tvrde } \\
\text { Moderate hard }\end{array}$ & $8-12$ & $1,43-2,15$ & $142,80-214,20$ \\
\hline $\begin{array}{l}\text { Prilično tvrde } \\
\text { Quite hard }\end{array}$ & $12-18$ & $2,15-3,22$ & $214,20-321,30$ \\
\hline Tvrde / Hard & $18-30$ & $3,22-5,35$ & $321,30-535,50$ \\
\hline $\begin{array}{l}\text { Vrlo tvrde } \\
\text { Very hard }\end{array}$ & $>30$ & $>5,35$ & $>535,50$ \\
\hline
\end{tabular}


Tablica 2. Ukupna tvrdoća vode u nekim naseljima u Republici Hrvatskoj (izvor: Dadić, 2001)

Table 2 Total water hardness in some locations in the Republic of Croatia (source: Dadić, 2001)

\begin{tabular}{|c|c|c|c|}
\hline \multirow{2}{*}{$\begin{array}{c}\text { Red. } \\
\text { br. } \\
\text { Ordinal }\end{array}$} & \multirow[t]{2}{*}{$\begin{array}{l}\text { Naselje } \\
\text { Location }\end{array}$} & \multicolumn{2}{|c|}{$\begin{array}{c}\text { Ukupna tvrdoća } \\
\text { Total hardness }\end{array}$} \\
\hline & & ${ }^{\circ} \mathrm{nj}$ & $\mathrm{mg} \mathrm{CaCo}_{3} / \mathrm{L}$ \\
\hline 1 & Bjelovar & 13,8 & 246,0 \\
\hline 2 & Čabar & 14,4 & 257,0 \\
\hline 3 & Čakovec & 14,7 & 262,0 \\
\hline 4 & Daruvar & 3,1 & 56,0 \\
\hline 5 & Delnice & 10,7 & 191,0 \\
\hline 6 & Dubrovnik & 12 & 215,0 \\
\hline 7 & Dugo Selo & 22,1 & 396,0 \\
\hline 8 & Gospić & 12,7 & 228,0 \\
\hline 9 & Ivanec & 13,0 & 232,0 \\
\hline 10 & Ivanić Grad & 15,9 & 283,0 \\
\hline 11 & Karlovac & 13,6 & 242,0 \\
\hline 12 & Koprivnica & 15,2 & 271,0 \\
\hline 13 & Krapina & 16,7 & 299,0 \\
\hline 14 & Križevci & 13,4 & 240,0 \\
\hline 15 & Ludbreg & 18,9 & 338,0 \\
\hline 16 & Novigrad (Istra) & 19,1 & 340,0 \\
\hline 17 & Novska & 21,7 & 388,0 \\
\hline 18 & Ogulin & 11,0 & 196,0 \\
\hline 19 & Osijek & 16,5 & 294,6 \\
\hline 20 & Otok Biševo & 61,0 & 1086,0 \\
\hline 21 & Otok Lastovo & 52,0 & 940,0 \\
\hline 22 & Otok Mali Drvenik & 104,0 & 1864,0 \\
\hline 23 & Otok Murter & 35,0 & 625,0 \\
\hline 24 & Otok Premuda & 82,9 & 1480,0 \\
\hline 25 & Petrinja & 10,2 & 183,0 \\
\hline 26 & Rijeka & 7,0 & 125,5 \\
\hline 27 & Sisak & 11,5 & 205,0 \\
\hline 28 & Slavonski Brod & 21,0 & 375,0 \\
\hline 29 & Varaždin & 22,0 & 392,0 \\
\hline 30 & Velika Gorica & 22,7 & 406,0 \\
\hline 31 & Vinkovci & 13,8 & 246,0 \\
\hline 32 & Virovitica & 17,8 & 317,0 \\
\hline 33 & Vukovar & 14,9 & 266,0 \\
\hline 34 & Zagreb - Centar & 20,5 & 366,0 \\
\hline 35 & Zagreb - Črnomerec & 20,5 & 366,0 \\
\hline 36 & Zagreb - Dubrava & 22,1 & 394,0 \\
\hline 37 & Zagreb - Sesvete & 23,0 & 410,0 \\
\hline 38 & Zaprešić & 23,0 & 410,0 \\
\hline
\end{tabular}

neopasnim ili manje opasnim sredstvom. Jedno od mogućih zamjenskih sredstava za čišćenje metalnih sapnica jest limunska kiselina, koja je slaba organska kiselina, prirodni je konzervans, a upotrebljava se $\mathrm{u}$ prehrambenoj industriji kao aditiv, $u$ farmaceutskoj in- dustriji, kao i za omekšavanje vode. Limunska je kiselina aktivni sastojak nekih sredstava za čišćenje kupaonica i kuhinja. Otopinom limunske kiseline koncentracije $6 \%$ bez ribanja se mogu otkloniti mrlje tvrde vode na staklu, a u metalnoj se industriji upotrebljava za otapanje hrđe s čelika. Ujedno se primjenjuje i kao ekološki neškodljivo sredstvo za čišćenje. Na sobnoj je temperaturi u obliku bijeloga kristalnog praha. Limunska je kiselina slaba kiselina, ali ipak pri rukovanju njome treba biti oprezan te je potrebno nositi zaštitne naočale i rukavice. Naime, izloženost većim koncentracijama kiseline može dovesti do iritacije očiju i kože (tabl. 3). Zbog navedenih pozitivnih obilježja limunske kiseline cilj ovoga rada bio je pokus čišćenja metalnih sapnica vodenom otopinom limunske kiseline različitih koncentracija i temperature.

\section{MATERIJALI I METODE \\ 2 MATERIALS AND METHODS}

Materijal za istraživanja bile su standardne sušioničke metalne sapnice od nehrđajućeg čelika aksijalnog usmjerenja mlaza na kojima su postojale nakupine kamenca što su uzrokovale slabo raspršivanje vode u zrak u sušionici. Uzorci koji više nisu zadovoljavali uvjete praktične primjene prikupljani su tijekom duljega vremenskog razdoblja $\mathrm{u}$ industrijskom pogonu. Sapnice predviđene za tretiranje podijeljene su u dvije skupine: 1. sapnice koje ne zadovoljavaju uvjete uporabe, a imaju samo naslage kamenca (u tablicama označene kao: kam), 2. sapnice koje ne zadovoljavaju uvjete uporabe i na sebi imaju naslage kamenca, ali su usto tijekom duljeg vremena stajanja korodirale ( $\mathrm{u}$ tablicama označene kao: kor). Istraživanje je provedeno pri sobnim uvjetima: $t_{\mathrm{s}}=20^{\circ} \mathrm{C}, \varphi=58 \%$. Koncentracija limunske kiseline u destiliranoj vodi određena je preko masenih omjera uz pomoć staklene menzure i umjerene vage KERN 440-33N, s točnošću mjerenja $d=0,01 \mathrm{~g}$ i maksimalne mjerene mase $m=200 \mathrm{~g}$. Istraživanje (čišćenje sapnica) provedeno je u vodenoj otopini limunske kiseline različitih koncentracija i tijekom različitih vremena tretiranja. Za ispitivanje učinka iste koncentracije vodene otopine limunske kiseline sapnice su tretirane $\mathrm{u}$ vodenoj otopini sobne temperature i u provreloj vodenoj otopini, tj. sapnice su prokuhavane.

Određeno je osam različitih postupaka tretiranja. Pri čišćenju uzoraka prokuhavanjem najprije je proključala otopina, a tek su tada u nju stavljani uzorci koji su prokuhavani određeno vrijeme, prema utvrđenom rasporedu. Za svako tretiranje uzete su dvije

Tablica 3. Oznake opasnosti i upozorenja za limunsku kiselinu - monohidrat prema koncentraciji (izvor: Merck KGaA, 2011., Safety data sheet for Citric Acid Monohydrate)

Table 3 Hazard symbols and risk phrases for Citric Acid Monohydrate based on concentration (source: Merck KGaA, 2011, Safety data sheet for Citric Acid Monohydrate)

\begin{tabular}{|c|c|c|c|c|}
\hline $\begin{array}{c}\text { Koncentracija } \\
\text { Concentration }\end{array}$ & $\begin{array}{c}\text { Oznaka opasnosti } \\
\text { Hazard symbol }\end{array}$ & $\begin{array}{c}\text { Opis oznake opasnosti } \\
\text { Description of hazard symbol }\end{array}$ & $\begin{array}{c}\text { R-oznaka upozorenja } \\
\text { R risk phrase }\end{array}$ & $\begin{array}{c}\text { Opis oznake upozorenja } \\
\text { Description of risk phrase }\end{array}$ \\
\hline$\geq 99 \%$ & $\mathrm{Xi}$ & nadražujuće & $\mathrm{R} 36$ & $\begin{array}{c}\text { R36-nadražuje oči } \\
\text { Irritating to eyes }\end{array}$ \\
\hline
\end{tabular}


sapnice koje su korodirale i imale nakupine kamenca, dvije sapnice koje su imale samo nakupine kamenca te po jedna sapnica koja nije bila u uporabi, a na njoj su utvrđivane promjene dimenzija nakon tretiranja (provjera utječe li izloženost određenoj koncentraciji i temperaturi otopine te određenom vremenu tretiranja korozivno na tijelo sapnice). Promjene dimenzija provjeravane su umjerenim mikrometrom s točnošću mjerenja $d=0,01 \mathrm{~mm}$ i mjernim rasponom $0-25 \mathrm{~mm}$.

\section{Vodena otopina sobne temperature}

Postupak 1:

a) 5 minuta u $3 \%$-tnoj vodenoj otopini limunske kiseline sobne temperature,

b) 10 minuta u $3 \%$-tnoj vodenoj otopini limunske kiseline sobne temperature.

Postupak 2:

a) 5 minuta u $5 \%$-tnoj vodenoj otopini limunske kiseline sobne temperature,

b) 10 minuta u $5 \%$-tnoj vodenoj otopini limunske kiseline sobne temperature.

Postupak 3:

a) 5 minuta u $10 \%$-tnoj vodenoj otopini limunske kiseline sobne temperature,

b) 10 minuta u $10 \%$-tnoj vodenoj otopini limunske kiseline sobne temperature.

Postupak 4:

a) 5 minuta u $15 \%$-tnoj vodenoj otopini limunske kiseline sobne temperature,

b) 10 minuta u $15 \%$-tnoj vodenoj otopini limunske kiseline sobne temperature.

Provrela vodena otopina (prokuhavanje)

Postupak 5:

a) 5 minuta u provreloj $3 \%$-tnoj vodenoj otopini limunske kiseline,

b) 10 minuta u provreloj $3 \%$-tnoj vodenoj otopini limunske kiseline.

Postupak 6:

a) 5 minuta u provreloj $5 \%$-tnoj vodenoj otopini limunske kiseline,

b) 10 minuta u provreloj $5 \%$-tnoj vodenoj otopini limunske kiseline.

Postupak 7:

a) 5 minuta u provreloj $10 \%$-tnoj vodenoj otopini limunske kiseline,

b) 10 minuta u provreloj $10 \%$-tnoj vodenoj otopini limunske kiseline.

Postupak 8:

a) 5 minuta u provreloj $15 \%$-tnoj vodenoj otopini limunske kiseline,

b) 10 minuta u provreloj $15 \%$-tnoj vodenoj otopini limunske kiseline.

Radi lakšeg praćenja i usporedbe dobivenih rezultata, utvrđeno je šest stupnjeva ocjenjivanja uspješnosti čišćenja (tabl. 4) koji su primijenjeni za vizualnu ocjenu očišćenosti od kamenca i korozije. Za ocjenjivanje je također utvrđeno šest stupnjeva kvalitete raspršivanja vodene magle očišćenih sapnica (tabl. 5).

Za pripremu otopine upotrijebljena je destilirana voda i ACIDUM CITRICUM - monohydricum. Nakon čišćenja sve su sapnice testirane u klasičnim komornim sušionicama. Djelovanje limunske kiseline na očišće-
Tablica 4. Ocjene uspješnosti čišćenja

Table 4 Assessment of cleaning efficiency

\begin{tabular}{|c|l|}
\hline $\begin{array}{c}\text { Ocjena } \\
\text { Assessment }\end{array}$ & \multicolumn{1}{c|}{\begin{tabular}{c}
\multicolumn{1}{c|}{ Opis ocjene } \\
Assment description
\end{tabular}} \\
\hline 0 & $\begin{array}{l}\text { nije očišćeno } \\
\text { No cleaning }\end{array}$ \\
\hline 1 & $\begin{array}{l}\text { blago površinsko čišćenje } \\
\text { Slight surface cleaning }\end{array}$ \\
\hline 2 & $\begin{array}{l}\text { djelomično čišćenje } \\
\text { Partial cleaning }\end{array}$ \\
\hline 3 & $\begin{array}{l}\text { zadovoljavajuće čišćenje } \\
\text { Satisfactorily cleaning }\end{array}$ \\
\hline 4 & $\begin{array}{l}\text { vrlo dobro čišćenje } \\
\text { Very good cleaning }\end{array}$ \\
\hline 5 & $\begin{array}{l}\text { potpuno čišćenje } \\
\text { Complete cleaning }\end{array}$ \\
\hline
\end{tabular}

Tablica 5. Ocjena kvalitete raspršivanja vodene magle Table 5 Quality assessment of water mist dispersion

\begin{tabular}{|c|c|}
\hline $\begin{array}{c}\text { Ocjena } \\
\text { Assessment }\end{array}$ & $\begin{array}{c}\text { Opis ocjene } \\
\text { Assessment description }\end{array}$ \\
\hline 0 & $\begin{array}{l}\text { nema raspršivanja } \\
\text { No dispersion }\end{array}$ \\
\hline 1 & $\begin{array}{l}\text { loše raspršivanje uz krupne mlazove } \\
\text { Poor dispersion with massive jets }\end{array}$ \\
\hline 2 & $\begin{array}{l}\text { loše raspršivanje uz krupne kapi } \\
\text { Poor dispersion with big drops }\end{array}$ \\
\hline 3 & $\begin{array}{l}\text { dobro raspršivanje uz manje nedostatke } \\
\text { Good dispersion with minor flaws }\end{array}$ \\
\hline 4 & $\begin{array}{l}\text { odlično raspršivanje uz malo slabiji } \\
\text { intenzitet magle } \\
\text { Excellent dispersion with a little weaker mis } \\
\text { intensity }\end{array}$ \\
\hline 5 & $\begin{array}{l}\text { odlično raspršivanje } \\
\text { Excellent dispersion }\end{array}$ \\
\hline
\end{tabular}

nost sapnica te kvalitetu raspršivanja vodene magle ocijenile su dvije stručne osobe istodobno, i to na temelju vizualnih opažanja.

\section{REZULTATI}

\section{RESULTS}

U tablici 6. navedeni su rezultati tretiranja metalnih sapnica otopinom limunske kiseline sobne temperature koji se odnose na kvalitetu očišćenosti od kamenca i korozije, te na kvalitetu raspršivanja vodene magle. U tablici 7. navedeni su rezultati tretiranja metalnih sapnica otopinom limunske kiseline u provrelom stanju, a odnose se na kvalitetu očišćenosti od kamenca i korozije, te na kvalitetu raspršivanja vodene magle.

\subsection{Tretiranje vodenom otopinom limunske} kiseline sobne temperature

3.1 Treatment in the aqueous solution of citric acid at ambient temperature

Rezultati istraživanja pokazuju da tretiranje sapnica u vodenoj otopini limunske kiseline sobne temperature koncentracije 5 - $10 \%$ nema učinka bez obzira na trajanje obrade. Tek pri koncentraciji $15 \%$ otopina blago površinski očisti kamenac, ali u raspršivanju vodene magle nema poboljšanja. 
Tablica 6. Rezultati tretiranja vodenom otopinom limunske kiseline sobne temperature

Table 6 Results of treatment in the aqueous solution of citric acid at ambient temperature

\begin{tabular}{|c|c|c|c|c|c|c|c|}
\hline $\begin{array}{l}\text { Red. br. } \\
\text { Ordinal }\end{array}$ & $\begin{array}{c}\text { Oznaka } \\
\text { uzorka } \\
\text { Sample } \\
\text { designat. }\end{array}$ & $\begin{array}{l}\text { Faza } \\
\text { Phase }\end{array}$ & $\begin{array}{c}\text { Vrijeme } \\
\text { tretiranja } \\
\text { Time of } \\
\text { treatment } \\
\text { min }\end{array}$ & $\begin{array}{c}\text { Koncentracija } \\
\text { Concentration } \\
\\
\%\end{array}$ & $\begin{array}{c}\text { Ocjena } \\
\text { uklanjanja } \\
\text { kamenca } \\
\text { Assessment of } \\
\text { limescale } \\
\text { removal } \\
\end{array}$ & \begin{tabular}{|c|} 
Ocjena \\
uklanjanja \\
korozije \\
Assessment of \\
corrosion \\
removal \\
\end{tabular} & $\begin{array}{c}\text { Opis kvalitete } \\
\text { raspršivanja } \\
\text { vodene magle } \\
\text { Description of } \\
\text { quality of water } \\
\text { mist dispersion }\end{array}$ \\
\hline 1. & kam-1 & I. a) & 5 & 3 & 0 & - & 0 \\
\hline 2. & kam-2 & I. a) & 5 & 3 & 0 & - & 0 \\
\hline 3. & kor-1 & I. a) & 5 & 3 & 0 & 0 & 0 \\
\hline 4. & kor-2 & I. a) & 5 & 3 & 0 & 0 & 0 \\
\hline 5. & kam-3 & I. b) & 10 & 3 & 0 & - & 0 \\
\hline 6. & kam-4 & I. b) & 10 & 3 & 0 & - & 0 \\
\hline 7. & kor-3 & I. b) & 10 & 3 & 0 & 0 & 0 \\
\hline 8. & kor-4 & I. b) & 10 & 3 & 0 & 0 & 0 \\
\hline 9. & kam-5 & II. a) & 5 & 5 & 0 & - & 0 \\
\hline 10. & kam-6 & II. a) & 5 & 5 & 0 & - & 0 \\
\hline 11. & kor-5 & II. a) & 5 & 5 & 0 & 0 & 0 \\
\hline 12. & kor-6 & II. a) & 5 & 5 & 0 & 0 & 0 \\
\hline 13. & kam-7 & II. b) & 10 & 5 & 0 & - & 0 \\
\hline 14. & kam-8 & II. b) & 10 & 5 & 0 & - & 0 \\
\hline 15. & kor-7 & II. b) & 10 & 5 & 0 & 0 & 0 \\
\hline 16. & kor-8 & II. b) & 10 & 5 & 0 & 0 & 0 \\
\hline 17. & kam-9 & III. a) & 5 & 10 & 0 & - & 0 \\
\hline 18. & kam-10 & III. a) & 5 & 10 & 0 & - & 0 \\
\hline 19. & kor-9 & III. a) & 5 & 10 & 0 & 0 & 0 \\
\hline 20. & kor-10 & III. a) & 5 & 10 & 0 & 0 & 0 \\
\hline 21. & kam-11 & III. b) & 10 & 10 & 0 & - & 0 \\
\hline 22. & kam-12 & III. b) & 10 & 10 & 0 & - & 0 \\
\hline 23. & kor-11 & III. b) & 10 & 10 & 0 & 0 & 0 \\
\hline 24. & kor-12 & III. b) & 10 & 10 & 0 & 0 & 0 \\
\hline 25. & kam-13 & IV. a) & 5 & 15 & 1 & - & 0 \\
\hline 26. & kam-14 & IV. a) & 5 & 15 & 1 & - & 0 \\
\hline 27. & kor-13 & IV. a) & 5 & 15 & 1 & 0 & 0 \\
\hline 28. & kor-14 & IV. a) & 5 & 15 & 1 & 0 & 0 \\
\hline 29. & kam-15 & IV. b) & 10 & 15 & 1 & - & 0 \\
\hline 30. & kam-16 & IV. b) & 10 & 15 & 1 & - & 0 \\
\hline 31. & kor-15 & IV. b) & 10 & 15 & 1 & 0 & 0 \\
\hline 32. & kor-16 & IV. b) & 10 & 15 & 1 & 0 & 0 \\
\hline
\end{tabular}

kam - sapnice koje ne zadovoljavaju uvjete uporabe, a na sebi imaju samo naslage kamenca / Nozzles not adequate for use, having only deposits of limescale; kor - sapnice koje ne zadovoljavaju uvjete uporabe, na sebi imaju naslage kamenca, ali su tijekom duljeg stajanja i korodirale / Nozzles not adequate for use, having deposits of limescale and corrosion as they were out of order for long

\subsection{Tretiranje provrelom vodenom otopinom} limunske kiseline

3.2 Treatment in the boiled aqueous solution of citric acid

Na slici 1. prikazana je višekratno upotrebljavana sapnica prije čišćenja provrelom vodenom otopinom limunske kiseline, dok je na slici 2. prikazana ista sapnica nakon čišćenja.

Sa sapnica koje su čišćene provrelom vodenom otopinom limunske kiseline koncentracije $3 \% \mathrm{u}$ trajanju 5 minuta kamenac je zadovoljavajuće očišćen, korozija je blago površinski očišćena, a sapnice nakon čišćenja odlično raspršuju vodenu maglu, uz malo slabiji intenzitet magle.

U sapnica tretiranih provrelom vodenom otopinom limunske kiseline koncentracije $3 \%$ u trajanju 10 minuta razina očišćenosti od kamenca i korozije jednaka je kao pri čišćenju $3 \%$-tnom otopinom u trajanju 5 mi-

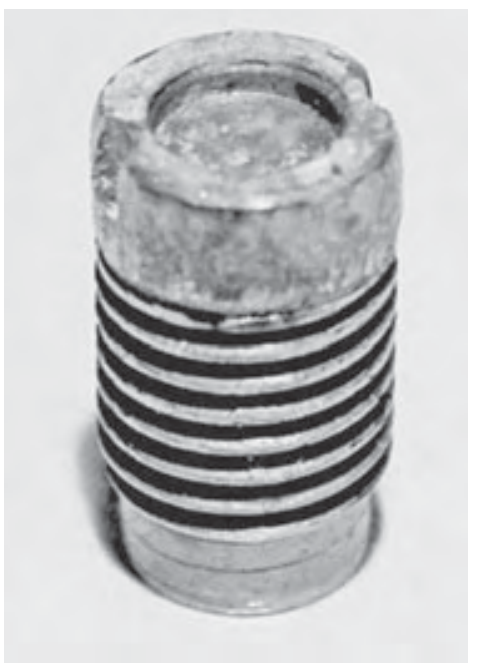

Slika 1. Sapnica prije čišćenja

Figure 1 Nozzle before treatment 
Tablica 7. Rezultati tretiranja provrelom vodenom otopinom limunske kiseline

Table 7 Results of treatment in the boiled aqueous solution of citric acid

\begin{tabular}{|c|c|c|c|c|c|c|c|}
\hline $\begin{array}{l}\text { Red. br. } \\
\text { Ordinal }\end{array}$ & $\begin{array}{c}\text { Oznaka } \\
\text { uzorka } \\
\text { Sample } \\
\text { designat. }\end{array}$ & $\begin{array}{l}\text { Faza } \\
\text { Phase }\end{array}$ & $\begin{array}{c}\text { Vrijeme } \\
\text { tretiranja } \\
\text { Time of } \\
\text { treatment } \\
\text { min }\end{array}$ & $\begin{array}{c}\text { Koncentracija } \\
\text { Concentration } \\
\\
\%\end{array}$ & $\begin{array}{c}\text { Ocjena } \\
\text { uklanjanja } \\
\text { kamenca } \\
\text { Assessment of } \\
\text { limescale } \\
\text { removal } \\
\end{array}$ & $\begin{array}{c}\text { Ocjena } \\
\text { uklanjanja } \\
\text { korozije } \\
\text { Assessment of } \\
\text { corrosion } \\
\text { removal } \\
\end{array}$ & $\begin{array}{c}\text { Opis kvalitete } \\
\text { raspršivanja } \\
\text { vodene magle } \\
\text { Description of } \\
\text { quality of water } \\
\text { mist dispersion }\end{array}$ \\
\hline 1. & kam-17 & V. a) & 5 & 3 & 3 & - & 4 \\
\hline 2. & kam-18 & V. a) & 5 & 3 & 3 & - & 4 \\
\hline 3. & kor-17 & V. a) & 5 & 3 & 3 & 1 & 4 \\
\hline 4. & kor-18 & V. a) & 5 & 3 & 3 & 1 & 4 \\
\hline 5. & kam-19 & V. b) & 10 & 3 & 3 & - & 5 \\
\hline 6. & kam-20 & V. b) & 10 & 3 & 3 & - & 5 \\
\hline 7. & kor-19 & V. b) & 10 & 3 & 3 & 1 & 5 \\
\hline 8. & kor-20 & V. b) & 10 & 3 & 3 & 1 & 5 \\
\hline 9. & kam-21 & VI. a) & 5 & 5 & 3 & - & 5 \\
\hline 10. & kam-22 & VI. a) & 5 & 5 & 3 & - & 5 \\
\hline 11. & kor-21 & VI. a) & 5 & 5 & 3 & 1 & 5 \\
\hline 12. & kor-22 & VI. a) & 5 & 5 & 3 & 1 & 5 \\
\hline 13. & kam-23 & VI. b) & 10 & 5 & 3 & - & 5 \\
\hline 14. & kam-24 & VI. b) & 10 & 5 & 3 & - & 5 \\
\hline 15. & kor-23 & VI. b) & 10 & 5 & 3 & 1 & 5 \\
\hline 16. & kor-24 & VI. b) & 10 & 5 & 3 & 1 & 5 \\
\hline 17. & kam-25 & VII. a) & 5 & 10 & 4 & - & 5 \\
\hline 18. & kam-26 & VII. a) & 5 & 10 & 4 & - & 5 \\
\hline 19. & kor-25 & VII. a) & 5 & 10 & 4 & 1 & 5 \\
\hline 20. & kor-26 & VII. a) & 5 & 10 & 4 & 1 & 5 \\
\hline 21. & kam-27 & VII. b) & 10 & 10 & 4 & - & 5 \\
\hline 22. & kam-28 & VII. b) & 10 & 10 & 4 & - & 5 \\
\hline 23. & kor-27 & VII. b) & 10 & 10 & 4 & 1 & 5 \\
\hline 24. & kor-28 & VII. b) & 10 & 10 & 4 & 1 & 5 \\
\hline 25. & kam-29 & VIII. a) & 5 & 15 & 5 & - & 5 \\
\hline 26. & kam-30 & VIII. a) & 5 & 15 & 5 & - & 5 \\
\hline 27. & kor-29 & VIII. a) & 5 & 15 & 5 & 2 & 5 \\
\hline 28. & kor-30 & VIII. a) & 5 & 15 & 5 & 2 & 5 \\
\hline 29. & kam-31 & VIII. b) & 10 & 15 & 5 & - & 5 \\
\hline 30. & kam-32 & VIII. b) & 10 & 15 & 5 & - & 5 \\
\hline 31. & kor-31 & VIII. b) & 10 & 15 & 5 & 3 & 5 \\
\hline 32. & kor-32 & VIII. b) & 10 & 15 & 5 & 3 & 5 \\
\hline
\end{tabular}

kam - sapnice koje ne zadovoljavaju uvjete uporabe, a na sebi imaju samo naslage kamenca / Nozzles not adequate for use, having only deposits of limescale; kor - sapnice koje ne zadovoljavaju uvjete uporabe, na sebi imaju naslage kamenca, ali su tijekom duljeg stajanja i korodirale / Nozzles not adequate for use, having deposits of limescale and corrosion as they were out of order for long

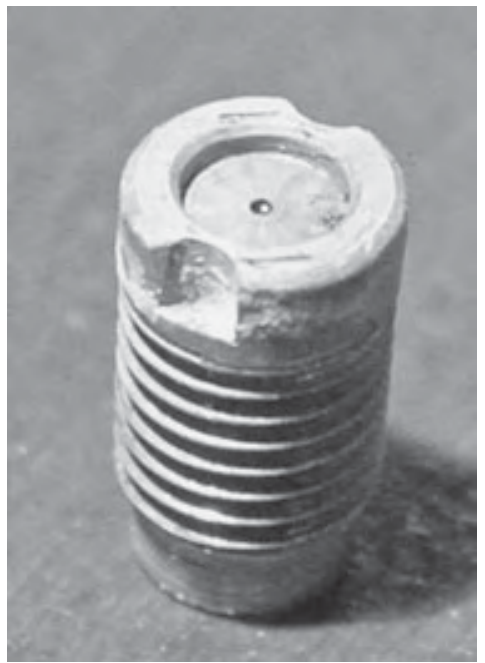

Slika 2. Sapnica nakon čišćenja Figure 2 Nozzle after treatment nuta, dok se znatnije poboljšanje vidi u raspršivanju vodene magle - ono je odlično. Isti su rezultati postignuti i $5 \%$-tnom otopinom u trajanju od 5 i 10 minuta.

Sa sapnica čišćenih provrelom vodenom otopinom limunske kiseline koncentracije $10 \%$ u trajanju 5 minuta znatno je poboljšano uklanjanje kamenca, koje je vrlo dobro. Isti su rezultati postignuti i $10 \%$-tnom otopinom, u trajanju 10 minuta.

$\mathrm{Na}$ sapnicama tretiranim vodenom otopinom limunske kiseline koncentracije $15 \%$ u trajanju 5 min poboljšano je uklanjanje kamenca, koji je u potpunosti nestao, te je poboljšana očišćenost od korozije, tj. djelomično je nestala.

Na sapnicama tretiranim vodenom otopinom limunske kiseline koncentracije $15 \%$ u trajanju 10 minuta poboljšano je uklanjanje korozije, koje je zadovoljavajuće. 


\section{DISKUSIJA}

\section{DISCUSSION}

U sušioničkoj je praksi najveći problem činjenica da se u trenutku pojave problema traži brzo, trenutačno rješenje, bez pokušaja da se shvati mehanizam nastanka problema. Ako se i nađe trenutačno rješenje, problem se ubrzo zaboravi, te se ne vodi nikakva evidencija o uzrocima, mehanizmu nastanka problema ili rješenju. U takvim je uvjetima ponovno pojavljivanje istog problema nakon određenog vremena unaprijed „zajamčeno“ (Welling, 2000). Uvijek je bolje djelovati preventivno na stvaranje naslaga kamenca nego riskirati neodgovarajuće navlaživanje i nemogućnost postizanja parametara sušenja. Postoje različiti načini omekšavanja vode. Osim standardnoga - uz pomoć soli, jedan je od zanimljivijih tretiranje „tvrde vode“ elektromagnetskim poljem permanentnog magneta, pri čemu je dokazano da taj postupak smanjuje sadržaj iona kalcija, što pridonosi smanjenju nastanka tvrdih naslaga kamenca na stijenkama (Gabrielli i dr., 2001). Za uspješnu primjenu magnetskog tretmana ,tvrde vode“ izuzetno je bitan i izbor materijala vodovodne cijevi jer je dokazano da su nevodljivi materijali najučinkovitiji za takvu vrstu tretiranja (Alimi, i dr., 2009). Uređaji za magnetski tretman „tvrde vode“ radi suzbijanja taloženja kamenca u uporabi su već dulje od pola stoljeća, a prvi komercijalni uređaj patentiran je u Belgiji 1945. (Vemeiren, 1958). Valja napomenuti da unatoč velikom broju različitih uređaja za magnetsko tretiranje vode koji se nude na tržištu, a što bi se moglo smatrati pokazateljem učinkovitosti magnetskih polja na stvaranje naslaga kamenca, većina neovisnih ispitivanja o performansama uređaja još su dosta kontroverzna (MacAdam i Parsons, 2004).

Iz rezultata dobivenih ovim istraživanjem vidljivo je da čišćenje uzoraka hladnom otopinom limunske kiseline nije dalo značajnije rezultate, najvjerojatnije zbog prekratkog vremena izloženosti otopini, dok je čišćenje uzoraka prokuhavanjem dalo odlične rezultate, čak i pri najmanjoj koncentraciji i najkraćem trajanju. Sve sapnice koje su prokuhavane bile su zadovoljavajuće očišćene i spremne za ponovnu uporabu. Iako se prokuhavanjem u otopinama manjih koncentracija za testirana vremena nisu u potpunosti očistile naslage kamenca s vanjskih stijenki sapnica, njime su u potpunosti pročišćeni prolazni putovi vode unutar sapnica. Pri većim koncentracijama čakje uočena znatnija očišćenost od korozije s površina sapnica. Također je utvrđeno da čišćenje sapnica otopinom limunske kiseline ne smanjuje nazivne dimenzije sapnice, tj. otopina limunske kiseline ne djeluje nagrizajuće na stijenke metalnih sapnica, kako upotrebljavanih, tako i neupotrebljavanih, što je utvrđeno naknadnim pokusom. Postoji mogućnost da se nakon višegodišnjeg tretiranja iste metalne sapnice vodenom otopinom limunske kiseline uoči neznatno nagrizajuće djelovanje na tijelo sapnice, ali bi o tome trebalo provesti daljnja dugotrajna istraživanja. Rukovanje limunskom kiselinom nema štetnih posljedica za osobe koje njome rukuju jer je također poznato da se limunska kiselina upotrebljava u prehrambenoj indu- striji i u kućanstvima, za konzumaciju. Limunska je kiselina jeftina, dostupna, relativno neopasna, neagresivna i ne nagriza tijelo metalne sapnice.

\section{ZAKLJUČAK \\ 5 CONCLUSION}

Na temelju rezultata istraživanja i diskusije može se zaključiti da se tvrde naslage kamenca mogu uspješno očistiti provrelom vodenom otopinom limunske kiseline, a da se ne ošteti tijelo metalne sapnice. Iako je ispitivanje provedeno industrijskom limunskom kiselinom, ona je po svom sastavu i koncentraciji identična konzumnoj limunskoj kiselini koja se prodaje u maloprodajnim prehrambenim trgovinama. Zbog niske cijene limunske kiseline pri prokuhavanju je preporučena i uporaba većih koncentracija limunske kiseline u vodenoj otopini kako bi se postiglo potpunije čišćenje u kraćemu vremenskom roku. Limunskom je kiselinom moguće očistiti i plastične sapnice, ali se one ne smiju prokuhavati kako se plastično tijelo sapnica ne bi rastopilo, već ih je potrebno kratkotrajno umakati u kipuću otopinu limunske kiseline. Praktičnom primjenom rezultata ovog istraživanja $\mathrm{u}$ industrijskim uvjetima potvrđeni su svi navedeni zaključci.

\section{Zahvala - Acknowledgement}

Zahvaljujemo Drvnoj industriji Novoselec i direktoru g. Šimi Svetini, dipl. ing. za pomoć pri provedbi eksperimentalnog dijela ovog istraživanja.

\section{LITERATURA}

\section{REFERENCES}

1. Alimi, F.; Tlili, M.M.; Ben Amor, M.; Maurin, G.; Gabrielli, C., 2009: Effect of magnetic water treatment on calcium carbonate precipitation: Influence of the pipe material. Chemical Engineering and Processing, 48 (8): 1327-1332 http://dx.doi.org/10.1016/j.cep.2009.06.008.

2. Baker, J.S.; Judd, S.J.; Parsons, S.A., 1997: Antiscale magnetic pretreatment of reverse osmosis feedwater. Desalination, 110 (1-2): 151-166 http://dx.doi.org/10.1016/S0011-9164(97)00094-5.

3. Dadić, Ž., 2001: Priručnik o temeljnoj kakvoći vode u Hrvatskoj. Hrvatski zavod za javno zdravstvo, Zagreb, Hrvatska.

4. Gabrielli, C.; Jaouhari, R.; Maurin, G.; Keddam, M., 2001: Magnetic water treatment for scale prevention. Water Research, 35 (13): 3249-3259 http://dx.doi.org/10.1016/S0043-1354(01)00010-0.

5. Krpan, J., 1965: Sušenje i parenje drva. Šumarski fakultet Sveučilišta u Zagrebu, Zagreb, Hrvatska.

6. Legrand, L.; Leroy, P., 1990: Prevention of Corrosion and Scaling in Water Supply Systems. Ellis Horwood Series in Water and Waste Water Technology, New York, USA.

7. MacAdam, J.; Parson, A., 2004: Calcium carbonate scale formation and control. Reviews in Environmental Science and Bio / Technology. 3 (2): 159-169 http://dx.doi.org/10.1007/s11157-004-3849-1.

8. Pervan, S., 2000: Priručnik za tehničko sušenje drva. Sand, Zagreb, Hrvatska.

9. Šivak, M., 2002: Tehnologija pripreme tehničkih voda u termoenergetici. N.D.M.Š., Zagreb, Hrvatska. 
10. Vermeiren, T., 1958: Magnetic treatment of liquids for scale and corrosion prevention. Corrosion Technology. 5: 215-219.

11. Welling, J., 2000: Timber Drying Research - Industrial Needs and Scientific Expectations. 2 ${ }^{\text {nd }}$ Workshop of COST Action E15 „Quality Drying of Hardwood“, 11-13 September 2000, Sopron, Hungary.

12. *** Zakon o zaštiti na radu (Narodne Novine, br. 59/96., 94/96., 114/03., 100/04., 86/08., 116/08. i 75/09.).

13. ${ }^{* * *}$ Pravilnik o razvrstavanju, označavanju, obilježavanju i pakiranju opasnih kemikalija - Prilog 1 (Narodne Novine, br. 23/08. i 64/09.).

14. *** Merck KGaA, 2011: Safety data sheet for Citric acid monohydrate. Darmstadt, Germany.

\section{Corresponding address:}

Assistant MILJENKO KLARIĆ, MEng in Wood Technology

University of Zagreb, Faculty of Forestry

Wood Technology Department

Division for Material Technologies

Svetošimunska 25

HR-10002 Zagreb, CROATIA

e-mail: mklaric@sumfak.hr 